\title{
400 Years of Debris-Flow Activity and Triggering Weather Conditions: Ritigraben, Valais, Switzerland
}

\author{
M. Stoffel* $\S$ \\ I. Lièvre* \\ D. Conus* \\ M. A. Grichting* \\ H. Raetzo ${ }^{\dagger}$ \\ H. W. Gärtnert and \\ M. Monbaron* \\ *Department of Geosciences, Geography, \\ University of Fribourg (IGUF), Pérolles, \\ CH-1700 Fribourg, Switzerland. \\ $\dagger$ Swiss Federal Office for Water and \\ Geology (FOWG), Ländtestrasse 20, \\ CH-2503 Bienne, Switzerland. \\ $\ddagger$ Swiss Federal Institute for Forest, \\ Snow and Landscape Research (WSL), \\ Zürcherstrasse 111, 8903 Birmensdorf, \\ Switzerland. \\ §markus.stoffel@unifr.ch
}

\begin{abstract}
Three major rainfall events have caused considerable damage in the Valais region (Swiss Alps) since 1987. Substantial debris flows originating from periglacial environments were recorded during the August 1987 and September 1993 rainfall events, whereas no debris flows occurred in October 2000. This paper aims at putting these large-area events and the apparent increase in debris-flow frequency into a wider context by reconstructing the past debris-flow activity in the Ritigraben torrent (Mattertal, Valais) with dendrogeomorphological methods. Tree-ring analysis allowed the reconstruction of 53 events, going back to the year 1605. Previously, only 10 debris flows had been known for the torrent, and these were limited to the period between 1922 and 2002. Results further show that the apparently above-average concentration of events since 1987 was mainly caused by insufficient and short archival data. In fact, debris flows occurred even more frequently in the nineteenth century than they do today. The spatial distribution of injured trees in particular years further indicates that significant events, like the one in 1993, always occurred in the torrent. Finally, reconstructed event years were compared with archival data on flooding in neighboring catchments. The comparisons prove that large-area events like those in 1987, 1993, or 2000 have at least been as common in the past as they are today.
\end{abstract}

\section{Introduction}

Debris flows are one of the major types of destructive mass movements in Alpine areas. The process has been observed for more than a century (Berlepsch, 1861; Stiny, 1910), and archives contain reports on hazardous events of the past (e.g., Fux-Anthamatten, 2001). In Switzerland, research mainly started after the events in 1987 (VAW, 1992; Rickenmann and Zimmermann, 1993). The significant flooding and debris-flow series in September 1993 (Röthlisberger, 1994) or more recently in October 2000 (BWG, 2002) provided additional information on triggering and depositional processes. Furthermore, several test sites in the Swiss Alps have been equipped with measuring devices in order to improve knowledge about behavioral aspects of debris flows (Rickenmann et al., 2001; Hürlimann et al., 2003). Most of these data seem to prove that the number and the size of events remarkably increased over the past 25 years.

At best, precise data on past debris-flow activity cover only a few decades of the twentieth century. Archival data may furnish additional information on past events (Röthlisberger, 1991). However, these data generally do not reflect a detailed history of former events, and information on magnitudes remains exceptional. On forested debrisflow cones, dendrogeomorphological analyses may provide data on magnitude and frequency of past events (Alestalo, 1971; Strunk, 1995). In the Swiss Alps, the Multetta cone in Tschierv (Grisons; Baumann and Kaiser, 1999) and the Wildibach cone in Randa (Valais; Gers, 1998) have been analyzed with this method.

Therefore, the purpose of the research presented herein has been to study the frequency of past debris-flow activity of a torrent system having a periglacial origin. We report on results obtained from dendrogeomorphological analysis, in which growth anomalies in trees were used to date past debris-flow events. Reconstructed events were then compared to archival data on flooding in neighboring rivers, and the distribution of sites affected by flooding was analyzed. Special focus was placed on the analysis of triggering weather situations and the spatial distribution of sites affected by flooding.

\section{Study Area}

The study was conducted at the Ritigraben torrent, located on the west-facing slope of the Mattertal Valley (Valais, $46^{\circ} 11^{\prime} \mathrm{N}, 7^{\circ} 49^{\prime} \mathrm{E}$ ). As illustrated in Figure 1, geophysical (seismic refraction and direct current resistivity) data and bottom temperatures of the winter snow cover indicate that permafrost is prevalent in the source area of the Ritigraben torrent at $2600 \mathrm{~m}$ a.s.1. (Lugon and Monbaron, 1998). Direct observations of ice lenses after the debris flow in 1994 confirmed this interpretation (Gardaz et al., 1995). Finally, initial results from temperature measurements suggest that permafrost is relatively temperate and possibly in a unstable state (Herz et al., 2003). On a structural terrace situated between $1800 \mathrm{~m}$ and $1500 \mathrm{~m}$ a.s.l., the actual flow path crosses a large debris-flow cone. At the confluence with the receiving Mattervispa River at $1080 \mathrm{~m}$ a.s.l., depositional forms are lacking, and debris-flow material is being eroded by direct contact with the Mattervispa River. In addition to parts of the village of Grächen, the Ritigraben torrent endangers several roads on its path, including the main road to Zermatt (Bloetzer and Stoffel, 1998). The position of the structural terrace and the confluence are indicated in Figure 1.

According to Brigger et al. (1993) and Fux-Anthamatten (2001), nine events are noted in archives for the period 1922-1994. A further debris flow was recorded on August 28, 2002. A histogram of these events is given in Figure 2. Of all the known debris flows, half took place in the past 25 years $(1987,1991,1993,1994$, and 2002); this (apparent) increase of events is supposed to be the result of global warming conditions. That interpretation is supported by Rebetez et al. (1997), who tested the critical threshold of precipitation in relation to 


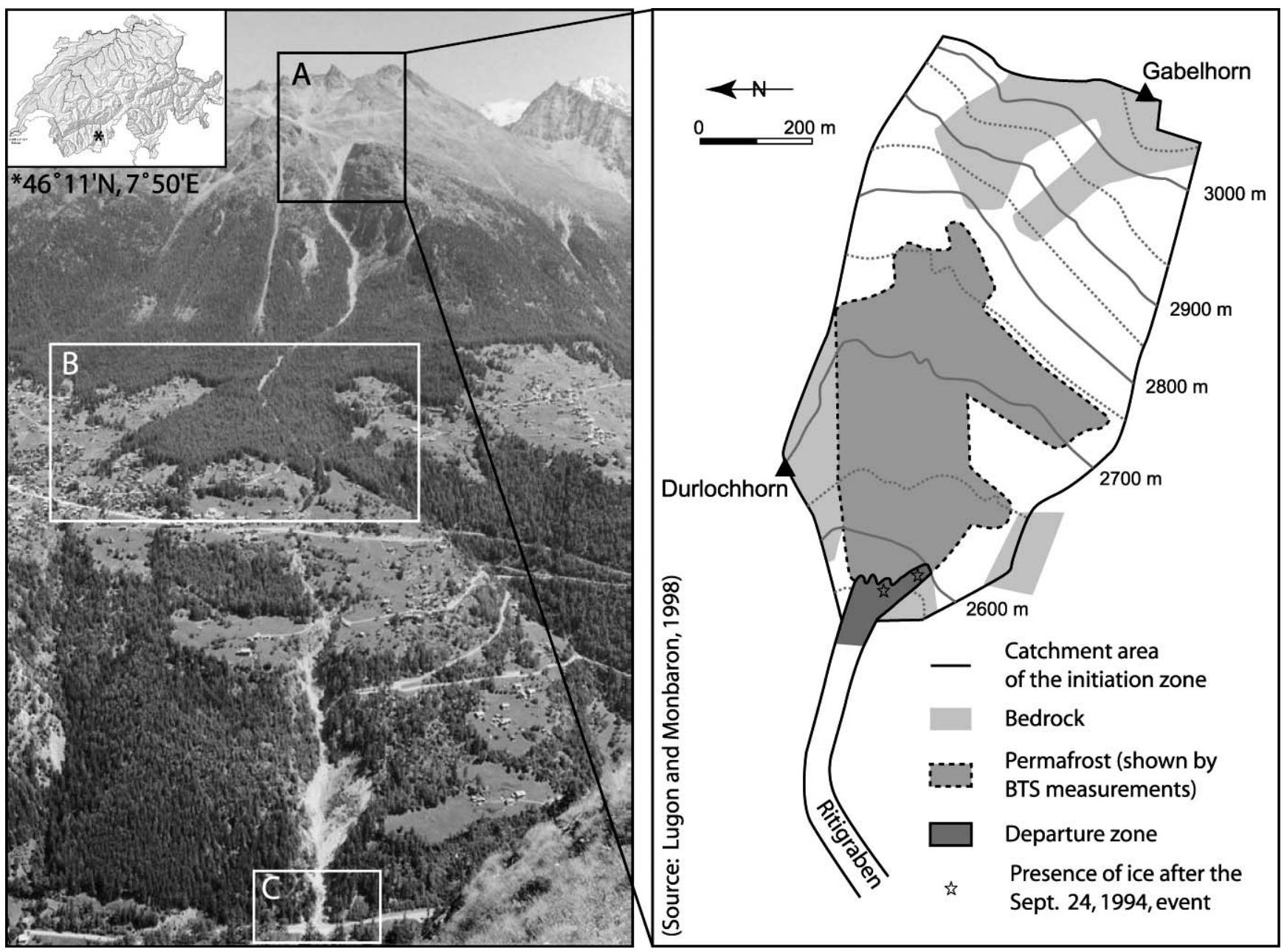

FIGURE 1. Catchment area of the Ritigraben torrent (Valais, Swiss Alps), showing the initiation zone (A), the village of Grächen and the debris-flow cone located on a structural terrace $(B)$, and the confluence with the Mattervispa River and the main road to Zermatt $(C)$. In the initiation zone, permafrost is prevalent, as indicated in the accompanying map (Lugon and Monbaron, 1998) (BTS-bottom temperature of the winter snow cover).

the triggering of debris flows. Their results show an increasing number of weather situations crossing the critical threshold.

Data on magnitudes of past events only cover the period from 1993 to the present. Although the 1994 and the 2002 events mobilized $5000 \mathrm{~m}^{3}$ (Dikau et al., 1996) and $3000 \mathrm{~m}^{3}$, respectively, some 60,000 $\mathrm{m}^{3}$ were transported during the 11 debris-flow surges on September 24, 1993. As a result, the actual flow path was deeply incised (Zimmermann et al., 1997). The surges of 1993 together constitute the largest event recorded in the archival data for the Ritigraben torrent.

On the basis of observations of the recent behavior of the Ritigraben torrent, we distinguish three different types of events: In type I events, debris flows in the Ritigraben are triggered by local or regional thunderstorms, as on August 28, 2002. During such events, debris flows may also occur in the adjacent torrents, but no flooding is caused in the major rivers of the Valais and Ticino Alps. In contrast, type II and type III events affect large areas, causing damage on both sides of the southern crest of the Alps (Valais, Ticino). These events commonly occur in autumn, when marked low-pressure air masses carry abundant rainfall from the Mediterranean Sea toward the southern crest of the Alps and penetrate the southernmost parts of the Valais Alps (Grebner, 1994). Figure 3 illustrates precipitation sums recorded during such weather conditions around September 24, 1993, and October 14, 2000. In both cases, rainfall triggered flooding in rivers within the Valais Alps (e.g., Mattervispa, Saaservispa, Vispa, Saltina, and Rhone). Simultaneously, rivers originating at the southern slope of the crest (Ticino Alps) caused substantial runoff, resulting in high water marks at Lago Maggiore. The positions of the aforementioned rivers and Lago Maggiore are shown in the enlarged map in Figure 4. During type II events (e.g., September 24, 1993), abundant flooding is accompanied by debris-flow activity in the Ritigraben torrent. In contrast, type III events represent large-area events with substantial flooding but apparently no debris-flow activity in the Ritigraben torrent and other debris-flow systems having a periglacial origin (e.g., October 14-16, 2000).

\section{Methods}

\section{GEOMORPHIC FORMS AND \\ DENDROGEOMORPHOLOGICAL ANALYSES}

On the structural terrace located between $1800 \mathrm{~m}$ and $1500 \mathrm{~m}$ a.s.l., geomorphic forms created by debris-flow activity (e.g., lobes, levees, and abandoned flow paths) were mapped at a scale of 1:1000. On the basis of the detailed geomorphic map, trees that have obviously been disturbed by debris flows were selected. Consequently, trees disturbed by other geomorphic processes (e.g., rockfall), browsing, or anthropogenic activity were disregarded.

From the selected trees, two cores were extracted with Suunto increment borers. The position of the sampled trees was indicated on the geomorphic map in order to link growth disturbances with 


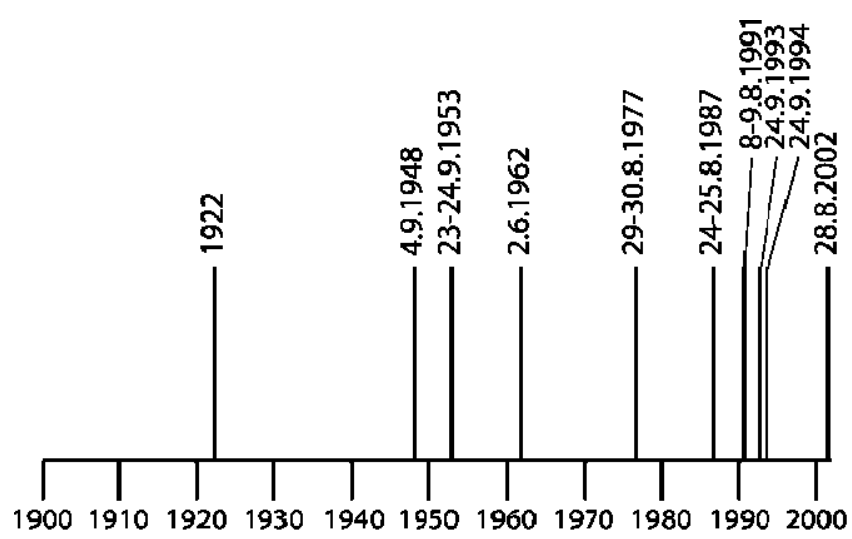

(Data sources: Brigger et al. [1993], Fux-Anthamatten [2001])

FIGURE 2. The debris-flow frequency derived from archives contains nine events between 1922 and 1994. The last debris flow occurred in August 2002.

geomorphic forms. In addition to the samples of disturbed trees, trees from undisturbed sites outside the cone were selected. After sample preparation, ring widths were measured by using digital LINTAB positioning tables, TSAP Version 3.0 (Time Series Analysis and Presentation) software, and Leica stereomicroscopes (Rinntech, 2003). The data were processed in accordance with the procedure described in Bräker (2002). Yearly-increment curves of disturbed trees were then crossdated with a reference chronology built with undisturbed trees, representing climatically driven tree growth of the area (Cook and Kairiukstis, 1990). Among the age-corrected disturbed samples, (1) the occurrence of compression wood as a reaction to the tilting of the stem (e.g., Shroder, 1980; Fantucci and Sorriso-Valvo, 1999), (2) the presence of abrupt growth changes after partial burying of the stems, the destruction of root mass, or the elimination of neighboring trees (Schweingruber, 1996), and (3) the initiation of tangential rows of resin ducts after traumatic disturbances of the cambium (Schweingruber, 2001) were taken into consideration for the dating of past debrisflow activity.

Reconstructed debris-flow event years in the Ritigraben were then compared to both archival data on flooding in rivers within the Valais region (Lütschg-Lötscher, 1926; Ruppen et al., 1979; Jossen, 1988; Röthlisberger, 1991; Imboden, 1996; Berchtold, 2002) and information on high water marks at Lago Maggiore (Ticino; Röthlisberger, 1991; Spinedi et al., 1995). As can be seen from Figure 4, the selected fluvial systems are located on both sides of the southern crest of the Alps. In all sites chosen for analysis, substantial damage was caused during both the September 1993 and October 2000 events. From the archival data existing for these systems, information was taken into consideration if (1) the seasonal timing of the flooding was known and (2) the event took place during the period of debris-flow activity in the Ritigraben, i.e., between June and October. Finally, flooding caused by glacier-lake outbursts was disregarded. Table 1 displays the river systems, data sources, and number of events taken into account for the period covered by Ritigraben event years (1605-2002) revealed by the tree-ring analysis.

From these data, indices of similarity and conditional probabilities were computed in order to compare debris-flow event years in the Ritigraben torrent with flooding in the other systems. The indices of similarity (indsi) express the degree of coincidence between two different data sets with values varying between 0 (no similarity) and 1 (identical sets). For the conditional probabilities (CP), event years at Ritigraben were first compared to events in one of the other systems $\left(\mathrm{CP}_{T_{1} T_{2}}\right)$. Numerical values represent the quotient of the total coincident events in a river $T_{2}$ divided by the total events at Ritigraben $\left(T_{1}\right)$. Similarly, flooding in the different river systems was then compared to event years at Ritigraben $\left(\mathrm{CP}_{T_{2} T_{1}}\right)$, where the total coincident events between a river $T_{2}$ and the Ritigraben $T_{1}$ were divided by the total events at the respective river $\left(T_{2}\right)$.

In a further step, the spatial distribution of sites affected by flooding was analyzed, and events were attributed to the three types of events (I, II, III) described in the study-area section. Simultaneously, the distribution of events within the summer to early autumn months (June through October) was analyzed and compared to the seasonal

Oct. $13-14,2000$ (48 $\mathrm{h}$ precipitation sums)

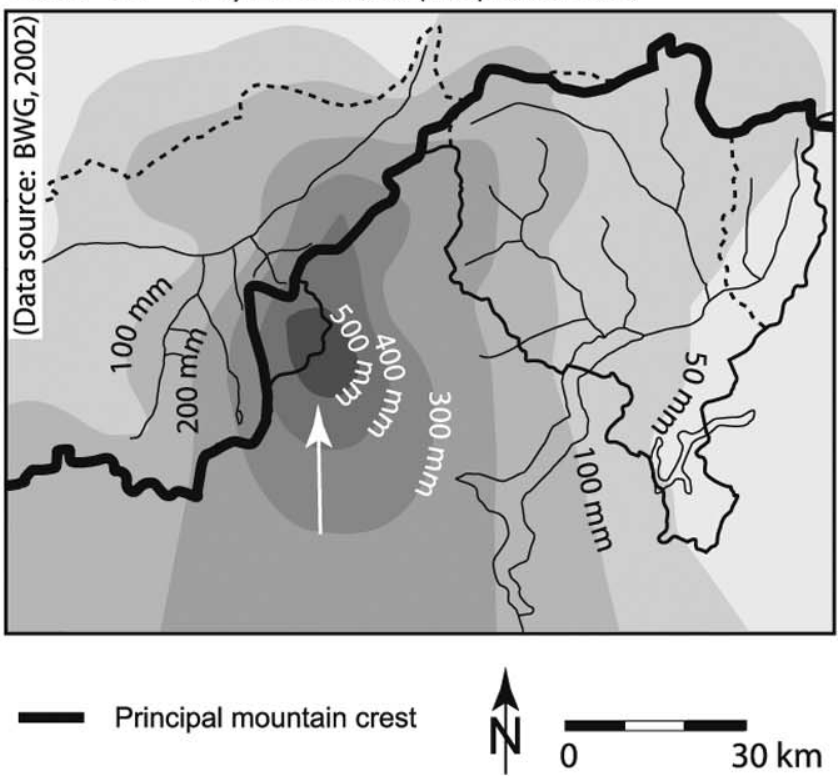

FIGURE 3. Rainfall intensities north and south of the principal mountain crest during the September 1993 (left) and the October 2000 (right) events. Location within Switzerland and Italy is shown in Figure 4. 


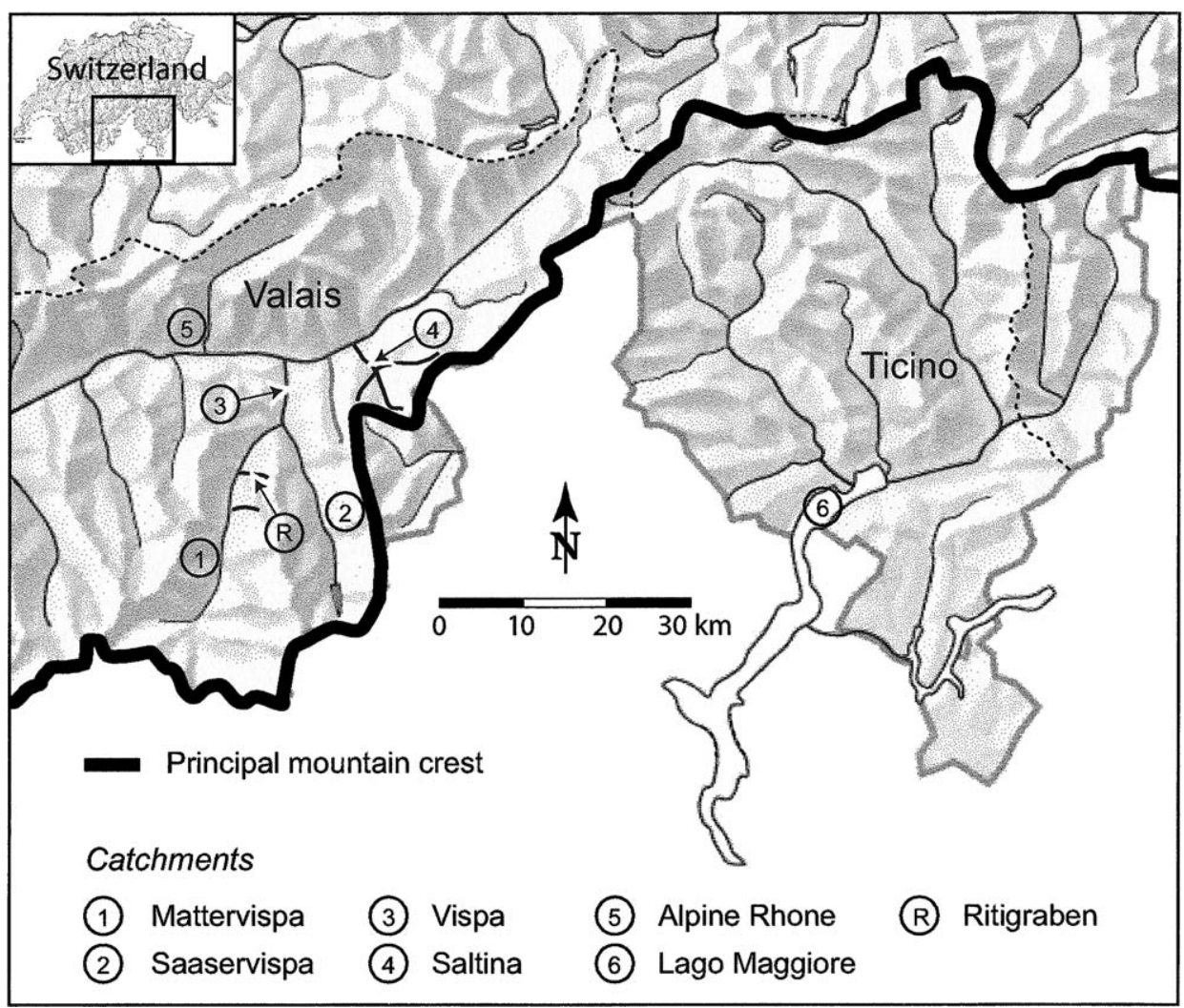

FIGURE 4. Location of the Ritigraben debris-flow system (R) and the rivers chosen for comparisons (1-5). South of the principle mountain crest, data on high water marks at Lago Maggiore (6) were used to complete the database. timing of Ritigraben events known from archives and direct observations (1922-2002).

The discussion section contains our comparison of the Ritigraben results with chronologies of the most significant flooding in the Swiss Alps (Hächler, 1991; Röthlisberger, 1991; Pfister, 1999). In that section, we also present data comparing our results with climate and glacier fluctuations in the Mattertal Valley (Holzhauser 1997, 2001).

\section{Results}

\section{DENDROGEOMORPHOLOGICAL ANALYSIS AND EVENT FREQUENCY}

Detailed geomorphic mapping on the debris-flow cone (scale 1:1000) covered $\sim 32$ hectares and allowed identification of 12 abandoned flow tracks and $>200$ depositional forms (Gärtner and Stoffel, 2002). More than 1200 disturbed trees (2450 cores) were sampled in order to date the depositional forms found on the cone. Analysis included samples of various conifer species, namely, European larch (Larix decidua Mill.), Norway spruce (Picea abies (L.) Karst.), and Swiss stone pine (Pinus cembra ssp. sibirica). The age of the trees covering the cone varied between 40 (AD 1962) and 510 years (AD 1492). The trees' average age was $\sim 250$ years.

Disturbed trees essentially showed three different types of growth disturbances. Scars only occasionally occurred, whereas the onset of compression wood was commonly found in the samples. The Picea abies illustrated in Figure 5, for instance, started to produce compression wood cells immediately after the tree was tilted by a debris flow in 1922. Trees with sudden growth releases, as illustrated by the Larix decidua sample in Figure 6, indicate that neighboring trees must have been eliminated by debris flows. Surviving trees profit by the improved growth conditions (e.g., light, nutrients, humidity) and produce larger tree rings. However, an interpretation of a debris flow on the basis of sudden growth releases was only taken into account if other trees featured traumatic rows of resin ducts or compression wood in the same year. In total, dendrogeomorphological analyses allowed reconstruction of 53 events between 1605 and 1994 (Lièvre, 2002): 1605, 1626, 1640, 1650, 1671, 1677, 1687, 1705, 1717, 1729, 1734, 1740, 1763, 1776, 1790, 1794, 1804, 1806, 1825, 1831, 1834, 1836, 1840, 1844, 1846, 1850, 1860, 1863, 1868, 1870, 1874, 1878, 1883, 1886, 1890, 1895, 1898, 1902, 1907, 1914, 1916, 1919, 1921, 1922, 1932, 1937, 1942, 1948, 1953, 1962, 1977, 1987, and 1993.

It can be seen from Figure 7 that within the period covered by archival data (1922-2002), three additional event years could be identified (1932, 1937, and 1942). In contrast, the events of 1991, 1994, and 2002 - known from archival data and direct observationsdid not leave the actual flow track, and trees on the cone remained undisturbed. Geomorphic forms on the debris-flow cone gave further evidence that some of the former channels were also deeply incised and that debris flows may have passed without disturbing trees. Therefore,

\section{TABLE 1}

Database with events attributable to the period June to October. [Data sources: $\mathbf{B e}=$ Berchtold (2002), $\mathbf{I m}=\operatorname{Imboden}(1996)$; Jo = Jossen (1988); Js = Jossen (2000); Lü = Lütschg-Lötscher (1926); Rö = Röthlisberger (1991); Ru = Ruppen et al. (1979); Sp = Spinedi et al. (1995)].

\begin{tabular}{|c|c|c|c|c|c|c|}
\hline Series & $\begin{array}{l}\text { River or } \\
\text { lake }\end{array}$ & Location & $\begin{array}{c}\text { Data } \\
\text { source }\end{array}$ & $\begin{array}{l}\text { Type of } \\
\text { hazard }\end{array}$ & $\begin{array}{c}\text { Period } \\
\text { covered }\end{array}$ & Events \\
\hline $\mathrm{R}$ & Ritigraben & Mattertal & & $\begin{array}{l}\text { debris } \\
\text { flows }\end{array}$ & $1605-2002$ & 56 \\
\hline 1 & Mattervispa & Mattertal & (Lü) & flooding & $1822-2002$ & 11 \\
\hline 2 & Saaservispa & Saastal & $(\mathrm{Ru})$ & flooding & 1589-2002 & 17 \\
\hline 3 & Vispa & Visp & (Lü, Be, Jo) & flooding & 1589-2002 & 26 \\
\hline 4 & Saltina & Brig & (Im, Lü) & flooding & 1331-2002 & 34 \\
\hline 5 & $\begin{array}{l}\text { Alpine } \\
\text { Rhone }\end{array}$ & Brig/Visp & (Lü, Js) & flooding & $1331-2002$ & 31 \\
\hline 6 & $\begin{array}{l}\text { Lago } \\
\qquad \text { Maggiore }\end{array}$ & Locarno & (Rö, Sp) & $\begin{array}{l}\text { high } \\
\text { watermarks }\end{array}$ & $1640-2002$ & 25 \\
\hline Total & & & & & & 200 \\
\hline
\end{tabular}




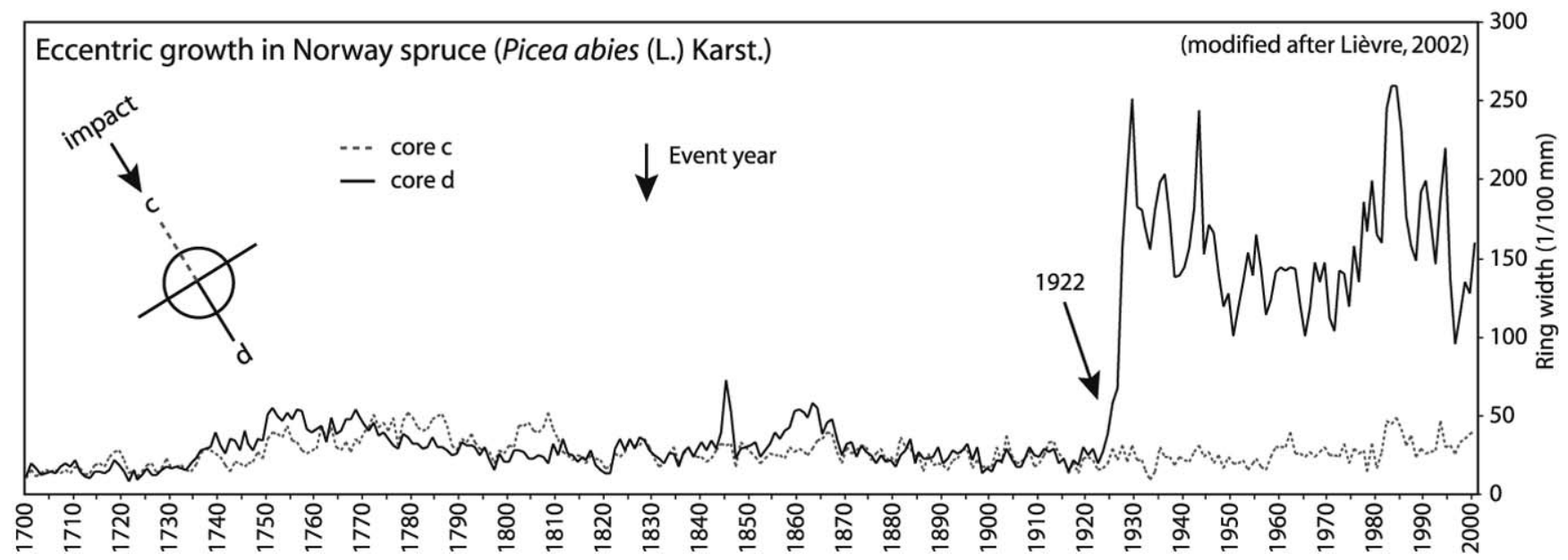

FIGURE 5. Eccentric growth of a Norway spruce (Picea abies (L.) Karst.) tilted by a debris flow. After the event in 1922, the tree tried to compensate for the tilting by producing larger increment rings on the downhill side (seen as compression wood in the tree rings of core d).

the reconstructed frequency shown in Figure 7 may not be exhaustive and has to be regarded as a minimum frequency.

\section{COINCIDENCE OF EVENT YEARS}

Reconstructed Ritigraben event years and flooding data in the selected rivers show significant similarities. Comparisons indicate that $68 \%$ of reconstructed debris-flow event years at Ritigraben correspond with flooding in at least one of the other catchments. This correspondence is especially true for the late nineteenth and the twentieth century, during which only the debris flow in 1919 appears nowhere else (Stoffel et al., 2003). The indices of similarity between the different data sets shown in Table 2 indicate that Ritigraben data best match with data on flooding in the Vispa (indsi $=0.33$ ) and the Saltina Rivers (indsi $=0.31$ ). In contrast, similarities of archival data for the Mattervispa and the Saaservispa Rivers appear to be less evident. The unexpectedly low figures for the Mattervispa and the Saaservispa Rivers are due to largely insufficient flooding data rather than to low similarities.

As shown in Table 2, the probability of debris-flow occurrence in the Ritigraben is highest when there is simultaneous flooding in the Saltina $\left(\mathrm{CP}_{T_{1} T_{2}}=0.44\right)$ or the Vispa $\left(\mathrm{CP}_{T_{1} T_{2}}=0.43\right)$ Rivers. In the opposite way, debris-flow occurrence in the Ritigraben is most frequent when flooding simultaneously occurs in the Alpine Rhone River $\left(\mathrm{CP}_{T_{2} T_{1}}=0.61\right)$. Reliable values are also obtained when flooding in the Saltina $\left(\mathrm{CP}_{T_{2} T_{1}}=0.54\right)$ and the Vispa Rivers $\left(\mathrm{CP}_{T_{2} T_{1}}=0.50\right)$ is considered.

\section{SEASONAL OCCURRENCE OF DEBRIS FLOWS}

Owing to the elevated position of the source area (2600-3200 m a.s.1.), Ritigraben debris flows only occur between June and September. Over the past four centuries, events were most frequent in August (43\%) and September (25\%). This concentration of events is especially true for the past $\sim 50$ years (1948-2002), where all but one event occurred in August or September. The exception, a debris flow that occurred in June 1962, was not initiated by heavy rain but by rapidly melting snow (Zimmermann et al., 1997).

Between the early nineteenth century and 1947, however, all events occurred in June, July (both 26\%), or August (48\%), and not a single event can be found in September. This subtle shift at the middle of the twentieth century from June, July, and August debrisflow activity to August and September activity can also be observed in the seventeenth and eighteenth century, when all attributable events took place in September (Stoffel et al., 2003).

\section{SPATIAL DISTRIBUTION OF SITES AFFECTED BY FLOODING AND TRIGGERING WEATHER SITUATIONS}

The analysis of the spatial distribution of sites affected by flooding shows that the three types of events (I, II, III) that have been observed during the past 25 years also commonly occurred in the past.

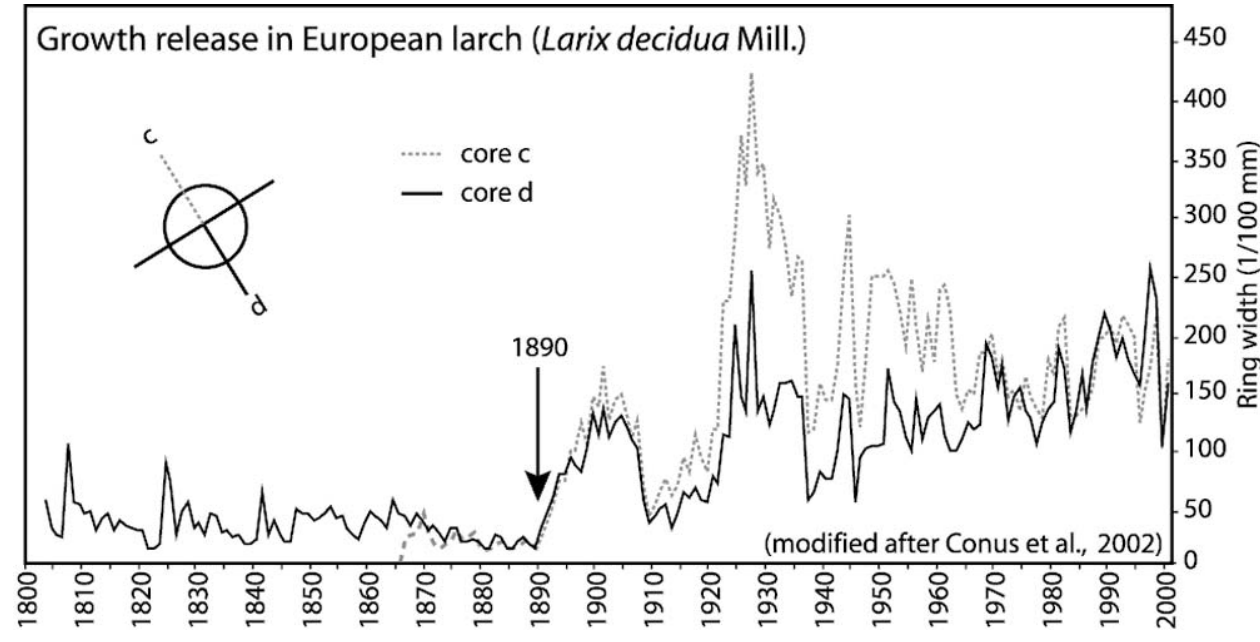

FIGURE 6. The sudden growth release of this European larch (Larix decidua Mill.) in 1890 represents improved growth conditions. In this particular case, the release seems to be the result of a removal of dominant neighboring trees by a debris flow. 

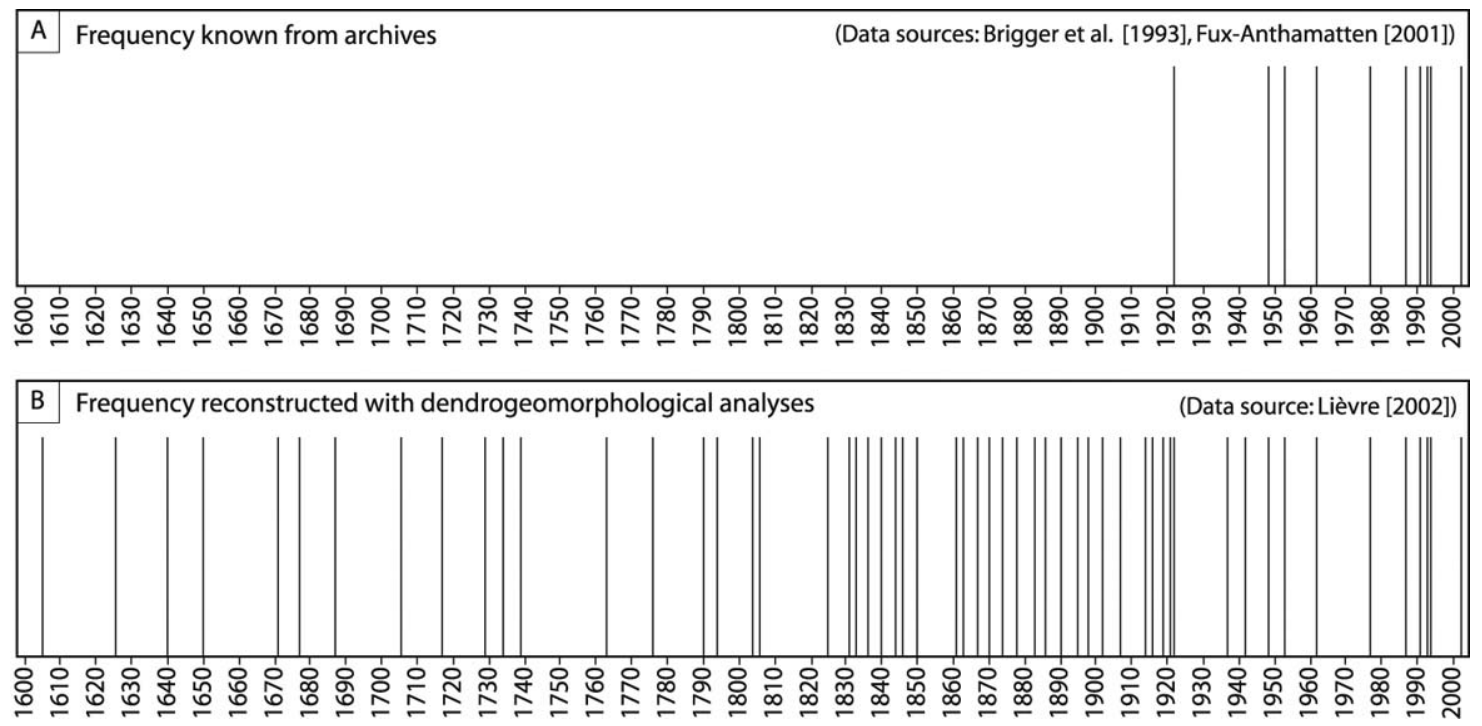

FIGURE 7. Debris-flow frequency as documented before (A) and after (B) the reconstruction of event years at Ritigraben with dendrogeomorphological methods.

\section{Type I Events: Local and Regional Events (Thunderstorms)}

Ritigraben debris flows in June, July, and (exceptionally), August appear to have been initiated by spatially limited thunderstorms. Besides the occurrence of debris flows in the Ritigraben, sites affected by flooding are restricted to the Saltina, Saaservispa, and/or Vispa Rivers. At Lago Maggiore, high water marks cannot be observed. Figure 8A gives the example of an event in 1850 , when a regional thunderstorm caused considerable damage in the Saltina and Vispa Rivers (Röthlisberger, 1991) and debris-flow activity was registered in trees at Ritigraben. Similar distributions can be found in August 1831, 1921, 1922, and 1977 as well as in July 1932, when sites affected by flooding were mostly restricted to the Ritigraben torrent and the Saltina River.

Other events seem to be triggered by even smaller meteorological events (local thunderstorms) located in the Mattertal Valley and south of the Ritigraben. As shown in Figure 8B, this distribution can be discerned in 1878, when debris flows simultaneously occurred in the Wildibach torrent, a system comparable to the Ritigraben and located $13 \mathrm{~km}$ south of it (Zurbriggen, 1952; Gers, 1998). The same distribution of sites affected by flooding can be found in 1907 and June 1942. On August 28, 2002, damage was restricted to the Ritigraben torrent, and no events were recorded in other systems in the Mattertal Valley.

Type II Events: Large-Area Events with Debris-Flow Activity (Persistent Precipitation)

Besides the local- to regional-scale events, a remarkable number of large-area events have occurred. Figure 9A shows the distribution of

TABLE 2

Ritigraben event years in comparison with flooding data of neighboring rivers and high water marks at Lago Maggiore [indsi: index of similarity, $\mathbf{C P}_{\mathbf{T}_{1} \mathbf{T}_{2}}$ : conditional probability (event in $T_{2}$ if event in $T_{1}$ ?), $C P_{T_{2} T_{1}}$ : conditional probability (event in $T_{1}$ if event in $\mathbf{T}_{2}$ ?)].

\begin{tabular}{lllll}
\hline \hline River 1 & \multicolumn{1}{c}{ River 2 } & indsi & $\mathrm{CP}_{T_{1} T_{2}}$ & $\mathrm{CP}_{T_{2} T_{1}}$ \\
\hline Ritigraben & Mattervispa & 0.20 & 0.25 & 0.55 \\
Ritigraben & Saaservispa & 0.26 & 0.36 & 0.47 \\
Ritigraben & Vispa & 0.33 & 0.50 & 0.43 \\
Ritigraben & Saltina & 0.31 & 0.54 & 0.44 \\
Ritigraben & Alpine Rhone & 0.29 & 0.61 & 0.40 \\
Ritigraben & Lago Maggiore & 0.23 & 0.35 & 0.38 \\
\hline
\end{tabular}

sites affected by flooding related to the period of persistent rainfall around September 24, 1993 (Röthlisberger, 1994). During this significant rainfall event (see Fig. 3), flooding occurred in the Rhone River and its tributaries (i.e., Mattervispa, Saaservispa, and Saltina Rivers). Simultaneously, high water marks were recorded at Lago Maggiore, and debris flows were triggered in the Ritigraben. Identical event patterns can be discerned for September 1640 (Fig. 9B), fall 1705, September 1740, August 1834, August 1846, August 1860, August 1868, August 1987, and September 1994. Similar to the timing of the recent type II events, our data indicate that throughout the past four centuries this meteorological situation exclusively occurred in August and September.

Type III Events: Large-Area Events without Debris-Flow Activity (Persistent Precipitation)

In contrast, Figure 10A shows that during type III events, no debris flows occur in the Ritigraben and other torrents originating at high-elevation sites. Most recently, in mid-October 2000, extensive precipitation (see Fig. 3) caused significant flooding in all rivers investigated and high water marks at Lago Maggiore without triggering debris flows in the Ritigraben. Figure 10B illustrates that patterns comparable to the one in October 2000 occurred in October 1755, October 1778, and October 1868 (Petrascheck, 1989). The abundant flooding in May 1872 is another example of widespread flooding in the Swiss Alps without debris-flow occurrence in the Ritigraben (Pfister, 1999). These results confirm our findings described herein on the seasonal timing of debris-flow activity, indicating that events are restricted to the period between June and September.

\section{Discussion}

Dendrogeomorphological analysis on the Ritigraben debris-flow cone allowed an extension of the known frequency of debris-flow events (1922-2002) back to the year 1605. The dendrogeomorphological reconstruction of past debris flows in the Ritigraben torrent is mainly limited by the age of the trees. Furthermore, (small) debris flows may remain in the flow track without necessarily disturbing trees on the cone. Hence, the events of 1991, 1994, and 2002, known from archival data and direct observations, could not be reconstructed with dendrogeomorphological methods. For these reasons, the 

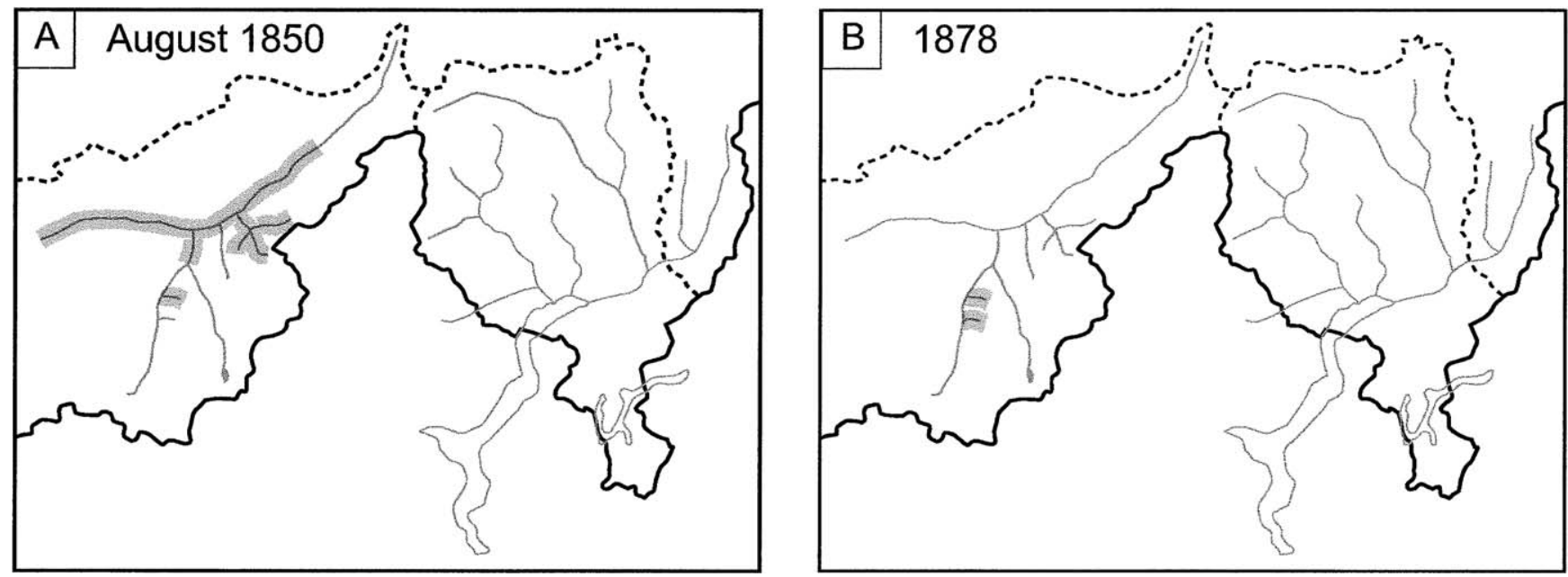

FIGURE 8. (A) Distribution of sites affected by flooding (shown by shading) during a type I event in August 1850. This pattern is common for events occurring between June and August and is caused by local thunderstorms. (B) In the 1878 event, sites affected by flooding were limited to the Wildibach (Gers, 1998) and the Ritigraben torrents.

reconstructed events only represent a minimum frequency of past debris-flow activity.

In a similar way, archival data appear to be rather incomplete. In the seventeenth and eighteenth century, a considerable number of Ritigraben event years do not have any analogues in the neighboring catchment areas. Some of these Ritigraben events may have been caused by locally limited triggers, like the rapid melting of snow in the source area, as evidenced for the June 1962 debris flow (Zimmermann et al., 1997). Furthermore, local phenomena (small summer thunderstorms), as on August 28, 2002, may also trigger debris flows without causing any flooding in neighboring catchment (type I events). Even so, it appears to be the fragmentary nature of the archival data (e.g., fragmentary data or omission of smaller events) that renders a certain number of comparisons impossible.

In contrast to other dendrogeomorphological analyses in the area (Gers, 1998), reconstructed debris-flow data in the Ritigraben torrent coincide very well with archival data. This statement is especially true for events with triggering weather situations similar to those in
September 1993. Throughout the twentieth century, evidence for such large-scale events can only be found in August 1987, September 1993, and to a certain extent in September 1994 (type II events). Therefore, these large-area events with simultaneous occurrence of debris flows in the Ritigraben appear to be at best as frequent today as they were in the past (eighteenth and nineteenth centuries).

In October 2000, the triggering weather situation was comparable to that in September 1993. In contrast, no debris flows occurred in the Ritigraben (type III events). Temperature measurements on both sides of the mountain crest indicate a local zero-degree isotherm at $3200 \mathrm{~m}$ a.s.l. and a snow line at $2800 \mathrm{~m}$ a.s.l. (Grebner and Hegg, 2002). The temperature dropped in the course of the event, and precipitation changed from rain to snowfall. Hence, the contribution of (sub)surface runoff in the upper catchment (see Fig. 1) was limited both in surface and time, which was why no debris flow occurred in the Ritigraben (Bardou and Delaloye, 2004). For the twentieth century, this type of event does not have any analogue. In contrast, events comparable to the one in October 2000 can be identified in the eighteenth and
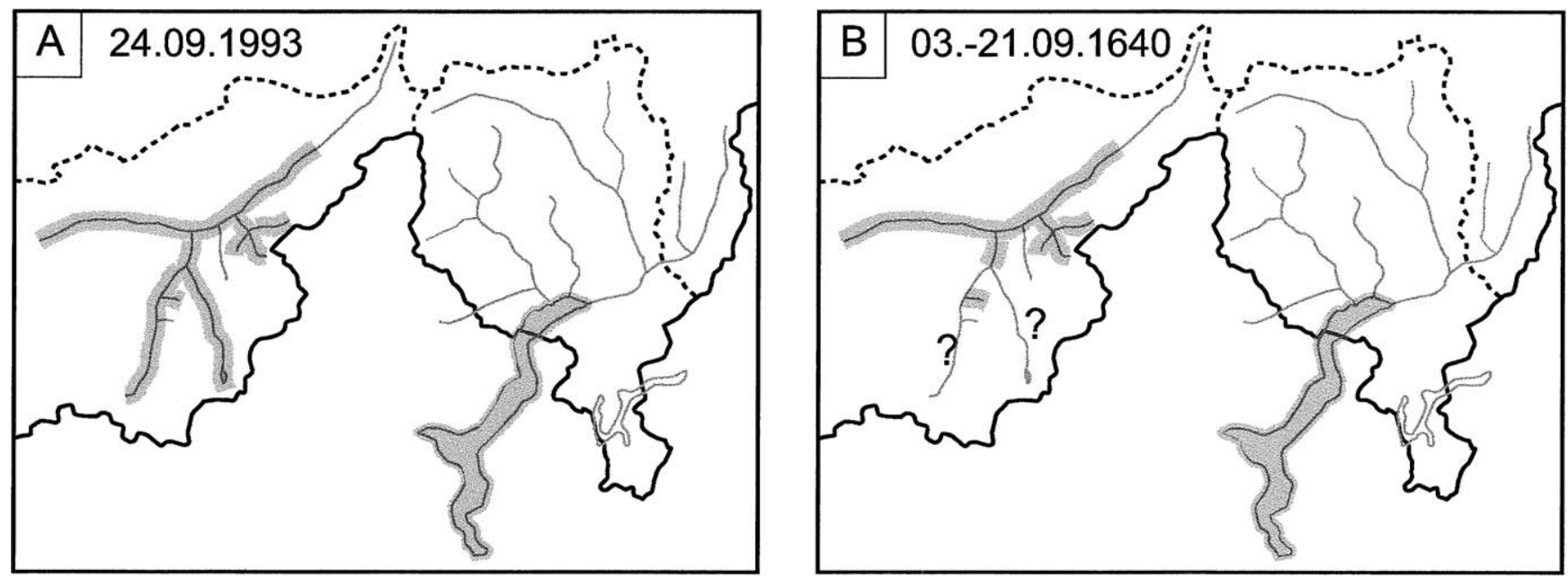

FIGURE 9. (A) Sites affected by flooding and presence of high water marks (shown by shading) during the September 24, 1993, events. Flooding caused severe damage in the Mattervispa, Saaservispa, Vispa, Saltina, Rhone valleys. Simultaneously, high water marks were recorded at Lago Maggiore. (B) The type II event can also be found in the data for September 3-21, 1640. No archival data are available for the Mattervispa and the Saaservispa (both marked with “?”). 

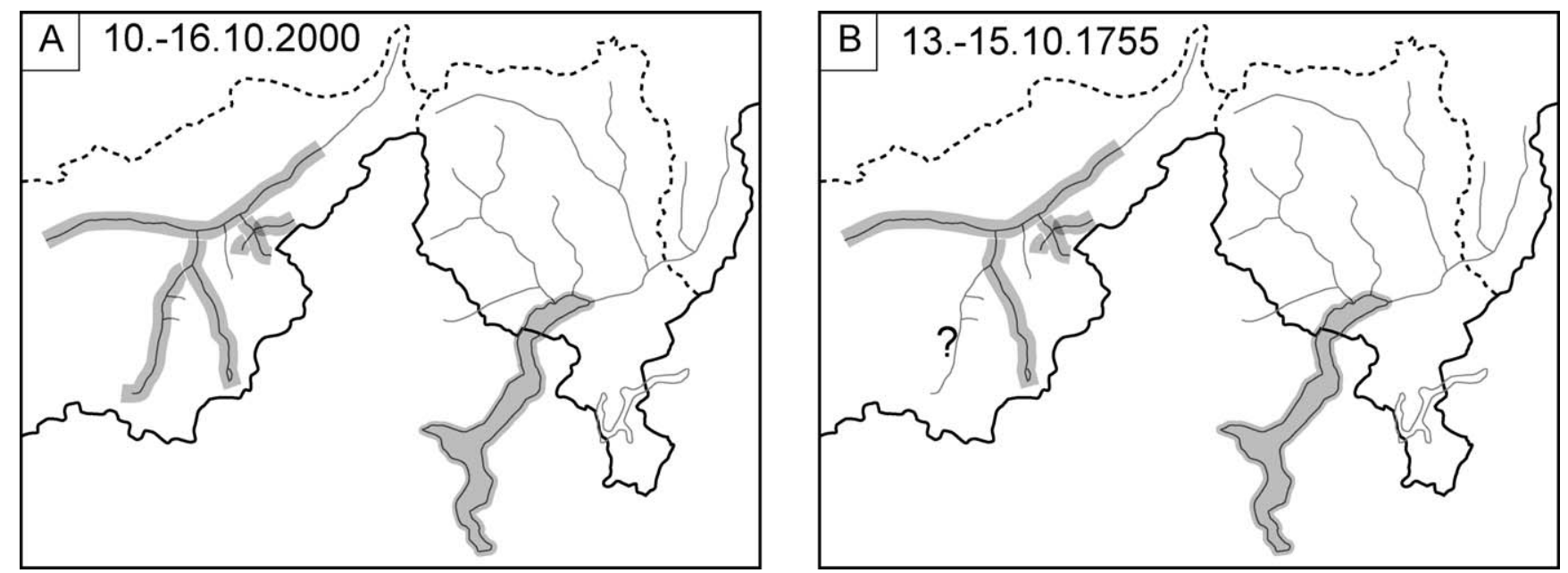

FIGURE 10. (A) October 10-16, 2000, flooding in the Upper Valais and Ticino regions (type II event). In contrast to the 1993 events, no debris flows occurred in the Ritigraben. (B) A similar distribution of sites affected by flooding can be found in the data for October 13-15, 1755. No archival data are available for the Mattervispa River.

nineteenth centuries, when they occurred more frequently than in the recent past.

The reconstruction of past debris-flow events and the repeatedly varying recurrence intervals strongly reduce the importance of the "sudden" increase of events since 1987. In fact, reconstructed Ritigraben data show that phases with accentuated activity and shorter recurrence intervals than today existed in the past, namely after 1827 and until the late nineteenth century. This period of short recurrence intervals of debris flows in the Ritigraben coincides with a phase of high flooding activity in major Swiss rivers (Hächler, 1991). After 1835 (and until the mid-1890s), considerable above-average precipitation sums in summer and fall are noted for the Swiss Alps (Pfister, 1999). Furthermore, increased debris-flow activity in the Ritigraben goes together with the last "Little Ice Age" advance of the Gorner Glacier (Zermatt), which reached its maximum extent about 1859 (Holzhauser, 2001). Similarly, the period of less frequent debrisflow activity after 1922 is also replicated in the major Swiss rivers, where low flooding frequencies were recorded between 1927 and 1975 (Hächler, 1991; Pfister, 1999).

Long-term fluctuations of late summer and fall precipitation sums, as evidenced by Pfister (1999), not only influence the flooding frequency in the Swiss and Ticino Alps, but they apparently drive the debris-flow activity of the Ritigraben torrent. On the debris-flow cone, analyses of the distribution of trees affected by single events further indicate that "large" events, as in $1993\left(60,000 \mathrm{~m}^{3}\right)$, repeatedly occurred in former times. Namely, the events of 1763, 1825, 1846, 1863, 1870, 1898, and 1922 appear to represent debris flows with substantial magnitudes. The importance of the 1993 debris-flow surges has to be thoroughly revised. Even so, correlations between global warming and modifications in the number or the size of debris-flow events, as hypothesized by, e.g., Haeberli and Beniston (1998), cannot, so far, be confirmed in the study area.

\section{Conclusions}

Reconstructed debris-flow data for the Ritigraben fit very well with flooding data in neighboring catchments. Large-area events in August and September are perfectly replicated in the reconstructed Ritigraben data. Owing to the high elevation of the source area and the presence of permafrost, the absence of debris flows during flooding events in late autumn, as seen in October 2000, appears to be a common phenomenon. Furthermore, the importance of the late-twentieth-century events has to be thoroughly revised. Events comparable to that in 1993 have previously existed in the region and do not represent a new phenomenon. Even the occurrence of several events within a short period of time can be observed in the mid-nineteenth century (i.e., six substantial events between 1834 and 1868). As the subtle shift of debris-flow occurrence from June, July, and August (1800-1947) to August and September (1948-2002) is supposed to be an effect of the changing climate at high-elevation sites (Beniston et al., 1997; Beniston, 2003), future studies on event reconstruction or prediction should turn their attention to this phenomenon.

\section{Acknowledgments}

The authors are grateful to the Swiss Federal Office for Water and Geology (FOWG, project BWG 804.3189.002.01.01), the Forest and Landscape Service, the Road and River Engineering Service (both Canton of Valais), and the Ritigraben communities of St. Niklaus and Grächen for important financial support. Reynald Delaloye and Franziska Keller provided helpful comments on the manuscript. Last but not least, Fran E. King and Mary C. Eberle are warmly acknowledged for improving the English of this paper.

\section{References Cited}

Alestalo, J., 1971: Dendrochronological interpretation of geomorphic processes. Fennia, 105: 1-139.

Bardou, E., and Delaloye, R., 2004: Effects of ground freezing and snow avalanche deposits on debris flows in alpine environments. Natural Hazards and Earth System Science, 4: 519-530.

Baumann, F., and Kaiser, K. F., 1999: The Multetta debris fan, Eastern Swiss Alps: A 500-year debris flow chronology. Arctic, Antarctic, and Alpine Research, 31(2): 128-134.

Beniston, M., 2003: Climatic change in mountain regions: A review of possible impacts. Climatic Change, 59: 5-31.

Beniston, M., Diaz, H. F., and Bradley, R. S., 1997: Climatic change at high elevation sites. Climatic Change, 36: 232-254.

Berchtold, S., 2002: Zur Geschichte der Vispa-Hochwasser. Walliser Jahrbuch, 71: 59-65.

Berlepsch, H. U., 1861: Die Alpen in Natur- und Lebensbildern. Leipzig: Hermann Costenoble, 511 pp.

Bloetzer, W., and Stoffel, M., 1998: Klimawandel als Herausforderung für die Raumplanung der Vispertäler. In Bloetzer, W., Egli, T., 
Petrascheck, A., Sauter, J., and Stoffel, M. (eds.), Klimaänderungen und Naturgefahren in der Raumplanung - Methodische Ansätze und Fallbeispiele. Zürich: Vdf Hochschulverlag AG, 127-200.

Bräker, O. U., 2002: Measuring and data processing in tree-ring research-A methodological introduction. Dendrochronologia, 20: 203-216.

Brigger, K., Brigger, B., Chastonay, V., Lagger, R., Manz, R., Walter, R., and Walter, S., 1993: Naturlehrpfad Grächen. Denges: Stiftung $60 \mathrm{pp}$.

BWG (ed.), 2002: Hochwasser 2000-Les crues 2000. Berichte des Bundesamtes für Wasser und Geologie, Serie Wasser, 2: 1-248.

Conus, D., Grichting, M. A., and Lièvre, I., 2002: Analyses dendrogéomorphologiques complémentaires à l'étude de la fréquence des laves torrentielles sur le cône du Ritigraben. Fribourg: University of Fribourg, Research Report, 19 pp.

Cook, E. R., and Kairiukstis, L. A., 1990: Methods of dendrochronology-Applications in the environmental sciences. London: Kluwer, $394 \mathrm{pp}$.

Dikau, R., Gärtner, H., Holl, B., Kienholz, H., Mani, P., and Zimmermann, M., 1996: Untersuchungen zur Murgangaktivität im Mattertal, Wallis, Schweiz. In Proceedings of the International Symposium INTERPRAEVENT. Garmisch-Partenkirchen: Interpraevent, 397-408.

Fantucci, R., and Sorriso-Valvo, M., 1999: Dendrogeomorphological analysis of a slope near Lago, Calabria (Italy). Geomorphology, 30: $165-174$.

Fux-Anthamatten, S., 2001: Familien- und Dorfchronik von Grächen 1900-2000. Grächen: Eigenverlag, 632 pp.

Gardaz, J.-M., Lugon, R., and Monbaron, M., 1995: Prospection du pergélisol de montagne à l'aide de la méthode BTS (Alpes Valaisannes, Suisse). Berichte und Forschungen der Universität Fribourg, 10: 93-105.

Gärtner, H., and Stoffel, M., 2002: Detailed mapping and dendrogeomorphological analysis of a debris flow torrent in Switzerland. In Proceedings of the International Symposium, INTERPRAEVENT. Matsumoto: Interpraevent, 199-207.

Gers, E., 1998: Dendrogeomorphologische Frequenzanalyse von Murgangereignissen am Beispiel des Wildibaches im Mattertal, Wallis, Schweiz. Diploma thesis, University of Bonn, Bonn, Germany, 86 pp.

Grebner, D., 1994: Meteorologische Analyse des Unwetters von Brig und Saas Almagell vom 24. September 1993. wasser, energie, luft, 86: 41-44.

Grebner, D., and Hegg, C., 2002: Temperaturverlauf und Schneefallgrenze. In BWG (ed.), Hochwasser 2000-Les crues 2000. Berichte des Bundesamtes für Wasser und Geologie, Serie Wasser, 2: $42-46$.

Hächler, S., 1991: Hochwasserereignisse im schweizerischen Alpenraum seit dem Spätmittelalter. Raumzeitliche Rekonstruktion und gesellschaftliche Reaktionen. Diploma thesis, University of Berne, Berne, Switzerland, 93 pp.

Haeberli, W., and Beniston, M., 1998: Climate change and its impacts on glaciers and permafrost in the Alps. Ambio, 27: 258-265.

Herz, T., King, L., and Gubler, H., 2003: Microclimate within coarse debris of talus slopes in the alpine periglacial belt and its effects on permafrost. In Philipps, M., Springman, S. M., and Arenson, L. U. (eds.), Permafrost: Proceedings, $8^{\text {th }}$ International Conference on Permafrost. Zurich: Balkema Publishers, 383-387.

Holzhauser, H., 1997: Fluctuations of the Grosser Aletsch Glacier and the Gorner Glacier during the last 3200 years: New results. Paläoklimaforschung/Palaeoclimate Research, 24: 35-58.

Holzhauser, H., 2001: Der Vorstoss des Gornergletschers von 1791 bis zum Hochstand um 1859 im Spiegel historischer Bild- und Schriftquellen. Vierteljahresschrift der Naturforschenden Gesellschaft in Zürich, 146(4): 95-104.

Hürlimann, M., Graf, C., Rickenmann, D., Näf, D., and Weber, D., 2003: Murgang-Beobachtungsstationen in der Schweiz: Erste Messdaten aus dem Illgraben. Physische Geographie, 41: 105-115. Imboden, G., 1996: Die wilde Saltina. Baumeisterin des Städtchens Brig. Blätter aus der Walliser Geschichte, 28: 121-163.
Jossen, P., 1988: Visp: Die Vespia Nobilis. Brig: Rotten Verlag, 255 pp.

Kunz, P., and Rey, J. M., 1995: Intempéries du 23 septembre 1994 dans le Haut-Valais (Massif du Simplon): Répétition de l'événement de 1993 un an après. Bulletin de la Murithienne, 113: 3-19.

Lièvre, I., 2002: Détermination de la fréquence de laves torrentielles sur le torrent $d u$ Ritigraben (Valais, Suisse). Diploma thesis, University of Fribourg, Fribourg, Switzerland, 61 pp.

Lugon, R., and Monbaron, M., 1998: Stabilité des terrains meubles en zone de pergélisol et changements climatiques. Deux études de cas en Valais: Le Ritigraben (Mattertal) et la moraine du Dolent (Val Ferret). Zürich: Vdf Hochschulverlag AG, 101 pp.

Lütschg-Lötscher, O., 1926: Ueber Niederschlag und Abfluss im Hochgebirge: Sonderdarstellung des Mattmarkgebietes: Ein Beitrag zur Fluss- und Gletscherkunde der Schweiz. Zürich: Schweizerischer Wasserwirtschaftsverband, $479 \mathrm{pp}$.

Petrascheck, A., 1989: Die Hochwasser 1868 und 1987. Ein Vergleich. wasser, energie, luft, 81 (1-3): 1-8.

Pfister, C., 1999: Wetternachhersage. 500 Jahre Klimavariationen und Naturkatastrophen. Bern, Stuttgart, Wien: Paul Haupt, 304 pp.

Rebetez, M., Lugon, R., and Baeriswyl, P.-A., 1997: Climatic change and debris flows in high mountain regions: The case study of the Ritigraben torrent (Swiss Alps). Climate Change, 36: 371-389.

Rickenmann, D., and Zimmermann, M., 1993: The 1987 debris flows in Switzerland: Documentation and analysis. Geomorphology, 8: $175-189$.

Rickenmann, D., Hürlimann, M., Graf, C., Näf, D., and Weber, D., 2001: Murgang-Beobachtungsstationen in der Schweiz. wasser, energie, luft, 93(1-2): 1-8.

Rinntech, 2003: LINTAB_-Precision ring by ring. http://www. rinntech.com/Products/Lintab.htm.

Röthlisberger, G., 1991: Chronik der Unwetterschäden in der Schweiz. Berichte der Eidg. Forschungsanstalt für Wald, Schnee und Landschaft, 330: 1-122.

Röthlisberger, G., 1994: Unwetterschäden in der Schweiz im Jahre 1993. wasser, energie, luft, 86 (1-2): 1-8.

Ruppen, P. J., Imseng, G., and Imseng, W., 1979: Saaser Chronik 1200-1979. Visp: Mengis Druck und Verlag, 310 pp.

Schweingruber, F. H., 1996: Tree rings and environment. Dendroecology. Bern, Stuttgart, Wien: Paul Haupt, 609 pp.

Schweingruber, F. H., 2001: Dendrökologische Holzanatomie. Bern, Stuttgart, Wien: Paul Haupt, 472 pp.

Shroder, J. F., 1980: Dendrogeomorphology: Review and new techniques of tree-ring dating. Progress in Physical Geography, 4: $161-188$.

Spinedi, F., Kappenberger, G., Sartori, S., Ambrosetti, P., and Zala, E., 1995: Le alluvioni del 1993 sul versante sudalpino. Rapporti di Lavoro dell'ISM, 186: 1-19.

Stiny, J., 1910: Die Muren. Versuch einer Monographie mit besonderer Berücksichtigung der Verhältnisse in den Tiroler Alpen. Innsbruck: Verlag der Wagner'schen Universitäts-Buchhandlung, $139 \mathrm{pp}$.

Stoffel, M., Gärtner, H., Lièvre, I., and Monbaron, M., 2003: Comparison of reconstructed debris flow event years (Ritigraben, Switzerland) and existing flooding data in neighboring rivers. In Proceedings, $3^{\text {rd }}$ International Conference on Debris Flow Hazard Mitigation 2003. Rotterdam: Millpress, 243-253.

Strunk, H., 1995: Dendrochronologische Methoden zur Ermittlung der Murfrequenz und Beispiele ihrer Anwendung. Regensburg: Roderer Verlag, $196 \mathrm{pp}$.

VAW, 1992: Murgänge 1987. Dokumentation und Analyse im Auftrag des Bundesamtes für Wasserwirtschaft. Bericht Nr. 97.6. Zürich: VAW, $620 \mathrm{pp}$.

Zimmermann, M., Mani, P., Gamma, P., Gsteiger, P., Heiniger, O., and Hunziker, G., 1997: Murganggefahr und Klimaänderung —Ein GISbasierter Ansatz. Zürich: Vdf Hochschulverlag AG, 161 pp.

Zurbriggen, J., 1952: Täsch. Familienstatistik, Chronik und Kirche. Brig-Glis: Buchdruckerei Tscherrig-Tröndle, 413 pp.

Revised ms submitted December 2004 